Jurnal Konstruksi Hukum | ISSN: 2746-5055

Vol. 2, No. 3, September 2021 Hal. 582-587| Tersedia online di

https://www.ejournal.warmadewa.ac.id/index.php/jukonhum

DOI:http://doi.org/10.22225/jkh.2.3.3630.582-587

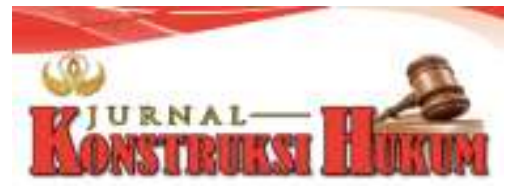

\title{
PERTANGGUNGJAWABAN HUKUM TERJADINYA KECELAKAAN DALAM BELAJAR MENGEMUDI
}

\author{
I Wayan Dandy Astrawan, Ketut Kasta Arya Wijaya, Luh Putu Suryani \\ Fakultas Hukum Universitas Warmadewa Denpasar, Bali- Indonesia \\ dandinstrawan465@emnil.com,kastnnrynwniinya@gmail.com,Dutusurvani099@Email.com
}

\begin{abstract}
Abstrak
Kendaraan bermotor baik itu motor dan mobil merupakan sarana pendu kung mobilitas orang serta barang guna memperlancar kehidu pan bermasyarakat. Hal tersebut mempengaru hi adanya pendidikan kursus mengemudi mobil di Indonesia yang didirikan oleh pengusaha. Tujuan dari penelitian ini adalah untuk mengetahui sanksi pidana bagi perusahaan jika terjadi kecelakaan dalam belajar mengemudi di jalan raya dan pertanggungjawaban perdata pihak perusahaan dalam hal terjadinya kecelakaan di jalan raya. Penelitian ini menggunakan penelitian hukum normatif. Hasil penelitian bahwa sanksi pidana bagi perusahaan ketika terjadi kecelakaan saat belajar mengemudi pidananya tidak diatur bagi perusahaan, namun pertanggungjawaban pidananya ditanggung oleh instruktur peserta didik sebagaimana ditegaskan dalam Pasal 79 ayat (1) dan (2), Undang- Undang Lalu Lintas dan Angkutan Jalan. Pertanggungjawaban perdata terhadap perusahaan dalam terjadinya kecelakaan adalah berkewajiban untu $\mathrm{k}$ memberikan bantuan kepada ahli war is atas biaya pengobat an dan pemahaman korban kalau kecelakaan mengakibatkan meninggal dunia.
\end{abstract}

Kata kunci: Kursus Mengemudi, Perusahaan, Sanksi pidana

\begin{abstract}
Motorized vehicles, both motorbikes and cars, are a means of supporting the mobility of people and goods in order to facilitate community life. This affects the existence of car driving courses in Indonesia which were founded by entrepreneurs. The purpose of this study is to determine the criminal sanctions for the company in the event of an accident in leaming to drive on the highway and the company's civil liability in the event of an accident on the highway. This research uses normative legal research. The results of the study show that criminal sanctions for companies when an accident occurs while leaming to drive are not regulated for the company, but the criminal liability is bome by the student instructor as confirmed in Article 79 paragraphs (1) and (2), Traffic and Road Transport Law. Civil liability to the company in the event of an accident is the obligation to provide assistance to the heirs for the cost of treatment and understanding of the victim if the accident results in death.
\end{abstract}

Keywords: Driving course, Company, criminal sanctions.

\section{PENDAhuluan}

Perkembangan oansportasi yang terjadi dewasa terjadi akibat pesatnya kebutuhan dari setiap individu untuk berpergian ke suatu tempat lain untuk mencari barang yang sedang dibutuhkan maupun hanya sekedar melakukan aktivitas sehari-hari, serta mendistribusikan barang ke suatu tempat yang membutuhkan barang tersebut. Transportasi sebagai salah satu komponen yang sangat penting bagi setiap orang pada dewasa ini. Transportasi sudah dianggap sebagai bagian dari kehidupan manusia karena memiliki sifat berpindah-pindah sebagai makhluk sosial. Maka dapat dilihat betapa pentingnya aturan mengenai lalu lintas (M N. Nasution, 2008). Pada saat ini di Indonesia tengah menghadapi permasalahan mengenai pemenuhan kebutuhan moda oansportasi umum yang layak bagi masyarakat, saat ini masyarakat cenderung memilih menggunakan kendaraan pribadi ketimbang menggunakan oansportasi umum, tujuan pemerintah Indonesia saat ini adalah untuk mengurangi peningkatan gas emisi yang dihasilkan dari kendaraan berinotor atau mobil yang digunakan sehari-hari oleh masyarakat. Diharapkan dengan hadimya transportasi umum di tengah lingkungan masyarakat dapat mengurangi tingkat polusi yang terjadi di seluruh wilayah negara Indonesia saat ini, namun realitanya, masyarakat enggan untuk menggunakan modal transportasi umum tersebut, dan memilih untuk menggunakan kendaraan pribadin ya untu k melakukan aktivitas sehari-hari (RS. Northop,2002). 
Seiring dengan meningkatnya jumlah pendudu $\mathrm{k}$, tentu saja kebutuhan mod a transportasi umum maupun pribadi terus meningkat, khusus mengenai mod a transportasi pribadi, saat ini pada lingkungan masyarakat banyak muncul jasa private mengemudi kendaraan bermotor khususnya mobil, jasa private mengemudi tersebut banyak menawarkan promo yang menggiurkan untuk menarik minat masyarakat untu $\mathrm{k}$ mengikuti private mengemudi, masyarakat sebagai pengguna jasa, akan didampingi oleh instruktur mengemudi ketika melakukan pelatihan mengemudi, sehingga instruktur tersebut mengawasi seseorang yang sedang belajar mengemudi. Adanya jasa private mengemudi yang ditawarkan kepada masyarakat, tentunya memberikan kemudahan bagi masyarakat untuk mengetahui bagaimana cara mengemudikan kendaraan bemotor secara aman, tugas dari seorang instruktur adalah mengajari dan membimbing seseorang yang akan pelajar mengemudi hingga mahir mengemudi di jalan raya dan mengetahui rambu-rambu lalu lintas ketika mengemudi kendaraan. Mengenai jasa pelayanan private mengemudi ini telah diatur di dalam Keputusan Menteri Perhubungan Nomor Km.36 Tahun 1994 Tentang Pendidikan Mengemudi Kendaraan Bermotor, yang mewajibkan setiap pen yedia layanan jasa mengemudi, agar setiap kendaraan yang digunakan pada saat pelatihan berisikan t ulisan latihan pada kaca bagian belakang, rem tambahan, dan setir tambahan yang sewaktu-waktu dapat dikemudikan oleh instruktur tersebut, tujuannya adalah untuk meminimalisir terjadinya kecelakaan lalu lintas pada saat melakukan pelatihan mengemudi.

Namun hal tersebut masih kurang memberikan jaminan dan kepastian huku m apabila terjadi kecelakaan lalu lintas yang diakibatkan oleh pelatihan mengemudi, dikarenakan pada saat pelatihan, instru ktur sewaktu-waktu mengarahkan peserta didikn ya untuk mengemudikan kendaraan pada jalan raya, dimana, si peserta didik in belum memiliki surat izin mengemudi (SIM) dan keahlian yang cukup matang untuk mengemudikan kendaraan bermobil pada jalan raya, hal tersebut sangat berpotensi untuk terjadinya kecelakaan lalu lintas. Saat ini apabila terjadi kecelakaan lalu lintas akibat dari private jasa mengemudi, siapakah yang akan mempertanggungjawabkan secara hu ku $\mathrm{m}$ akibat dari kecelakaan lalu lintas yang terjadi, apakah si peserta didik atau instru ktur dan perusahaan penyedia layanan jasa private mengemudi, mencintai negara Indonesia merupakan negara huku $\mathrm{m}$, hal tersebut diatur dalam pasal 1 ayat 3 Undang-undang Dasar negara Republik 1ndonesia pada dasamya menegaskan bahwa negara Indonesia adalah negara hu kurz artinya bahwa setiap tindakan negara dan warganya harus bertindak berdasarkan dan berlandaskan atas hu kum (M.N. Nasution, 2005)

Menurut Subekti (2002), Perjanjian adalah suatu peristiwa dimana seorang berjanji kepada suatu orang lain atau dimana kedua orang itu saling berjanji untuk melaksanakan suatu hal. Sedangkan menurut Prodjodikoro (1991) perjanjian adalah suatu hubungan hukum mengenai harta benda antara dua pihak dalam mana satu pihak berjanji untuk melakukan suatu hal atau untuk tidak melakukan suatu hal, sedangkan pihak lain berhak menuntut pelaksanaan janji itu.

Tanggung jawab yayasan penyedia jasa kursus mengemudi mobil memberikan tanggung jawab sepenuhnya kepada pihak instruktur, bentuk tanggung jawab instruktur meliputi tanggung jawab terhadap pengguna jasa dan tanggung jawab terhadap korban. Bentuk tanggung jawab yang dilakukan oleh instruktur apabila terjadi kerugian akibat kecelakaan pada saat pelatihan yaitu dengan membayar biaya kerusakan pada mobil tersebut misalnya saja dengan membawanya ke bengkel atau juga langsung dilakukan pemotongan gaji oleh pihak yayasan penyedia jasa kursus, tanggung jawab tetap dibebankan kepada instruktur oleh penyedia jasa (Azizah, 2019). Penyelenggaraan kursus harus dapat dipertanggungjawabkan kepada masyarakat dan Negara sebagai bagian dari akuntabilitas publik. Undang-undang Nomor 20 Tahun 2003 tentang Sistem Pendidikan Nasional pasal 62 mengamanatkan bahwa setiap satuan pendidikan formal dan nonformal wajib memperoleh izin Pemerintah atau Pemerintah Daerah. Syarat-Syarat Pendirian Lembaga Pelatihan Ketrampilan (Raenaldi et al., 2016).Pidana yang dijatuhkan atas pelanggaran kecelakaan lalu lintas terhadap calon pengemudi saat dengan peraturan perundangundangan yang ada. Disarankan agar merevisi UndangUndang Nomor 22 Tahun 2009 Pasal 79 ayat 2 dengan menyebutkan secara jelas yang bertanggungjawab pada saat terjadi kecelakaan apakah calon pengemudi atau instruktur pengemudi. belajar mengemudi seharusnya sesuai dengan Pasal 79 Ayat (2) Undang-undang Nomor 22 tahun 2009. Instruktur bertanggungjawab menangani apabila ada pelanggaran yang dilakukan oleh calon pengemudi.Tanggungjawab instruktur ditunjukkan lewat mencari jalan damai dengan korban sehingga tidak sampai ke persidangan (Jauhari et al., 2015).

Berdasarkan pemaparan diatas tujuan dari penelitian ini adalah untuk mengetahui sanksi pidana bagi perusahaan jika terjadi kecelakaan dalam belajar mengemudi di jalan raya, dan untuk 
mengetahui pertanggungjawaban perdata pihak perusahaan dalam hal terjadinya kecelakaan di jalan raya.

\section{METODE PENELITIAN}

Penelitian yang penulis gunakan adalah penelitian hukum normatif (Hartono, 1994) yaitu penelitian dilakukan dengan menganalisis peraturan perundang-undangan yang berlaku. Mengenai su mber bahan huku m yang digunakan terbagi atas Bahan Hu ku m Primer adalah bahan hukum yang utama yang menjadi dasar kajian penelitian ini. Bahan Hukum sekunder adalah adalah bahan hukum yang digunakan untu $\mathrm{k}$ menunjang atau membantu dalam memberikan pemahaman-pemahaman dan gambaran-gambaran serta teori-teori hu kurz yang digunakan untuk mengulas dan memecahkan persoalan-per soalan yang akan di teliti di dalam penelitian penulisan skripsi. Selanjutnya Bahan $\mathrm{Hu}$ kum Terrier adalah bahan hukum yang memberikan pedoman dan interpretasi bagi bahan hukum tingkat pertama dan kedua. Teknik pengu mpulan bahan dalam penelitian menggunakan teknik studi pustaka yaitu membaca, mencatat, mengutip, meringkas, dan menelaah informasi data dari peraturan atau literatur yang terkait dengan masalah tersebut. Setelah bahan huku m telah terku mpul melalui proses studi pustaka, dalam menganalisis bahan hu ku m yang telah terkumpul dalam penelitian ini penulis menggunakan uraian teknis, sistematisasi, argumentasi dan interpretasi hu kurz berdasarkan logika deduktif dan indu ktif. Ditinjau sesuai kebutuhan dengan menggunakan pendekatan kualitatif. Selanjutnya setelah bahan hu ku m primer dan sekunder terku mpul, ini akan diolah dan dianalisis menggunakan mettxle penanganan bahan hukum yang sistematis (Sunggono Bambang, 2002)

\section{HASIL DAN PEMBAHASAN}

\section{Sanksi Pidana Terhadap Perusahaan Apab ila Terjadi Kecelakaan Dalam Pelatihan Mengemudi di Jalan Raya}

Membahas mengenai pertanggungjawaban pidana, yang dimaksud dengan pertanggungjawaban pidana adalah, suatu konsep pertanggungjawaban apabila terdapat kesalahan, maka dari itu yang dimaksud dengan perranggungjawaban pidana adalah, seseorang dapat dikenakan pertanggungjawaban pidana apabila seseorang telah melanggar ketentuan yang terdapat dalam peraturan perundang-undangan, atau seseorang dapat disalahkan karena telah melanggar ketentuan yang terdapat dalam peraturan perundangan-undangan sehingga dapat dikenakan pertanggungjawaban pidana (Andi Hamzah, 1989). Membahas mengenai izin penyelenggaraan dari pelatihan private mengemudi yang diberikan oleh pemerintah terhadap penyedia layanan private mengemudi telah diatur didalam surat keputusan kementerian perhubungan KM 36 Tahun 1994 tentang Pendidikan mengemudi kendaraan Bermotor. Dalam memberikan izin mengemudi ini, kementerian perhubungan menggolongkan beberapa kategori yang harus dipenuhi oleh setiap penyedia layanan jasa private mengemudi, dimana layanan private jasa mengemudi ini terlebih dahulu harus mendapatkan izin private mengemudi dari depariemen pendidikan dan kebudayaan setempat, setelah mendapatkan izin dan rekomendasi kantor wilayah departemen perhubungan dan Kepala Kesatuan Kepolisian Republik Indonesia agar dapat diberikannya izin dan sertifikasi terhadap penyedia layanan private mengemudi.

Pada dasarnya layanan penyedia jasa private mengemudi haruslah memberikan pendampingan terhadap peserta didik yang hendak mengikuti private mengemudi, hal tersebut bertujuan untuk mengarahkan dan membimbing peserta didik yang hendak belajar mengemudi agar mampu menguasai dan memahami cara mengemudikan kendaraan mobil secara baik dan benar yang sesuai dengan rambu lalu lintas, untuk menghindari kecelakaan lalu lintas di kemudian hari. Membahas mengenai sanksi pidana apabila terjadinya kecelakaan lalu lintas yang diakibatkan dari layanan private jasa mengemudi, tentunya menjadi tanggung jawab dari instruktur yang menangani latihan pada saat terjadinya kecelakaan lalu lintas, hal tersebut telah diatur di dalam Pasal 79 ayat (1) dan ayat (2) Undang-undang Nomor 22 Tahun 2009 tentang Lalu Lintas dan angkutan jalan, menentu kan bahwa, setiap kecelakaan lalu lintas yang terjadi akibat dari pelatihan privat jasa mengemudi, merupakan tanggung jawab dari penyedia jasa layanan private mengemudi dan instruktur yang membimbing pesena private mengemudi saat terjadinya kecelakaan lal u lintas (Tjakranegara, 1995)

Mengenai saksi pidana terhadap kecelakaan yang diakibatkan dari private mengemudi ini juga diatur di dalam pasal 310 Undang-undang Nomor 22 Tahun 2009 tentang Lalu Lintas dan Angkutan Jalan, dimana apabila terjadi kecelakaan ringan yang mengakibatkan luka-luka ringan dapat dikenakan sanksi pidana beru pa 6 (enam) bulan penjara, untuk luka-lu ka sedang dapat dikenakan 
sanksi pidana penjara selama 1 (satu) tahun penjara, sedangkan apabila terjadi kecelakaan yang mengakibatkan luka-luka berat hingga kematian dapat dikenakan sanksi pidana penjara selama 5 (lima) tahun. Saat ini kepastian hukum terhadap peristiwa kecelakaan lalu lintas yang diakibatkan private jasa mengemudi masih menjadi tanda tanya besar terhadap masyarakat, mengenai siapakah yang akan diberikan sanksi pidana, apakah peserta penyedia jasa layanan private mengemudi atau menjadi tanggung jawab dari penyedia layanan jasa private mengemudi, dengan adanya ketentuan dari Pasal 79 ayat (1) dan ayat (2) Undang-undang Nomor 22 Tahun 2009 tentang lalu lintas dan angkutan jalan, yang menentukan bahwa setiap peristiwa kecelakaan yang diakibatkan dari jasa private mengemudi, sepenu hnya menjadi tanggung jawab instruktur yang menangani pelatihan private mengemudi pada saat terjadinya kecelakaan lalu lintas, selain itu tanggung jawab juga dikenakan terhadap penyedia layanan private mengemudi.

Berdasarkan hal tersebut, sedikitnya memberikan rasa kepastian hukum terhadap peserta yang mengikuti private mengemudi sena masyarakat yang menjadi korban kecelakaan akibat dari pelatihan mengemudi yang dilakukan pada jalan raya, mengingat peserta yang mengikuti pelatihan belu $\mathrm{m}$ memiliki keahlian yang mumpuni untuk mengendarai kendaraan mobil pada jalan raya, dari penjelasan tersebut diatas dapat diketahui bahwa peserta private mengemudi tidak dapat dikenakan sanksi pidana apabila terjadi kecelakaan lalu lintas akibat pelatihan mengemudi yang dilakukan pada jalan raya, dalam hal ini instruktur mempunyai tanggung jawab terhadap keamanan peserta private mengemudi dan pengguna jalan lainnya agar tidak terjadi kecelakaan lalu lintas, instruktur harus senantiasa memperhatikan dan membimbing peserta private mengemudi dan selalu siap sedia pada setir, rem dan spion tambahan yang tersedia pada kendaraan yang digunakan untuk melakukan pelatihan private mengemudi.

\section{Bentuk Pertanggungjawaban Perdata oleh Perusahaan Apabila Ter.jadi Kecelakaan di jalan Raya Dalam Pelaksanaan Bela,jar Mengemudi 1. Ganti Kerugian atas Kecelakaan Lalu Lintas}

Ganti kerugian dalam lapangan hukum perdata merupakan hubungan sebab akibat dari seseorang apabila terjadinya suatu perist iwa yang merugikan seseorang, ganti kerugian ini dimaksudkan memberikan rasa keadilan terhadap seseorang yang dirugikan akibat kesalahan yang dilakukan orang lain yang berakibat kerugian kepadanya, khususnya ganti kerugian atas peristiwa kecelakaan lalu lintas yang terjadi, hal ini dimaksudkan untuk memberikan rasa tanggung jawab terhadap si pelaku agar mengganti segala kerugian yang ditimbulkan akibat kecelakaan lalu lintas akibat kelalaian yang diakibatkan oleh dirinya. Sehingga dalam hal ini sanksi memainkan peran penting dalam kerangka penegakan hukum (penegakan hukum) dalam peristiwa kecelakaan lalu lintas yang terjadi akibat pelatihan private mengemudi. Secara umum, sanksi merupakan hukum yang dijadikan pedoman akibat dil aku kannya pelanggaran hukum yang dilakukan oleh seseorang. Dalam bidang hukum yang dikenal sebagai sanksi sipil, penjahat dan administrasi. Sanksi perdata adalah sanksi hu kum yang diketahui seseorang dapat menyebabkan kerugian bagi orang lain, oleh karena itu orang yang menyebabkan kerugian harus mengganti kerugiannya agar memberikan rasa tanggung jawab terhadap pelaku yang mengakibatkan kerugian terhadap orang lain, selain itu ganti kerugian yang bertujuan untu k memberikan rasa keadilan terhadap korban yang dirugikan, khususnya pada korban kecelakaan lalu lintas yang dilakukan oleh seseorang akibat kelalaiannya dalam mengemudikan kendaraan yang berujung terjadinya peristiwa kecelakaan (Bambang, 2002).

Ganti kerugian juga dapat ditimbulkan oleh Perbuatan melawan hu kum, Perbuatan Melawan huku m diatur dalam Pasal 1365 dan Pasal 1366 KUHPerdata, Pasal 1365 KUJHPerdata memberikan ketentuan tentang Perbuatan Melawan Hukum dengan tiap perbuatan melawan hukum, yang mendatangkan kerugian pada seorang lain, mewajibkan nrang yang karena salahnya menerbitkan kerugian itu, mengganti kerugian tersebut (Soekanto, 1990)

Dalam hal terjadinya kecelakaan lalu lintas yang diakibatkan karena kelalaian instruktur mengemudi yang disediakan oleh penyedia layanan jasa private mengemudi, sepenuhnya menjadi tanggung jawab dari penyedia layanan jasa private mengemudi, penyedia layanan jasa private mengemudi tidak dapat menuntut terhadap peserta private mengemudi untuk turut serta mengganti kerugian akibat dari peristiwa kecelakaan lalu lintas karena kelalaian instruktur dalam mengawasi peserta yang melakukan private mengemudi, dikarenakan berdasarkan keputusan Kementerian Perhubungan KM 36 Tahun 1994 tentang Pendidikan mengemudi kendaraan Bermotor, di dalam 
melakukan pelatihan pris'ate mengemudi, setiap kendaraan yang hendak digunakan untu k melakukan pelatihan haruslah dilengkapi dengan setir, rem, dan spion tambahan yang diawasi dan dikemudikan oleh instruktur tersebut untuk menghindari kecelakaan lalu lintas.

Selain itu berdasarkan Pasal 1365 dan Pasal 1366 K UHPerdata, Pasal 1365 KUHPerdata korban kecelakaan lalu lintas yang diakibatkan dari pelatihan mengemudi tersebut dapat meminta ganti keru gian akibat peristiwa kecelakaan lalu lintas yang ditimbulkan, selain itu peserta pelatihan yang turut menjadi korban akibat peristiwa kecelakaan tersebut dapat menuntut ganti kerugian terhadap penyedia layanan private mengemudi tersebut apabila diakibatkan oleh kelalaian instruktur yang menangani pelatihan private mengemudi pada saat terjadin ya peristiwa kecelakaan lalu lintas, dikarenakan dalam penyedia jasa private mengemudi seorang instruktur memiliki peranan yang penting dalam mengawasi peserta yang mengemudikan kendaraan untuk menghindari terjadinya kecelakaan lalu lintas.

\section{SIMPULAN DAN SARAN}

\section{Simpulan}

Dari penjelasan tersebut diatas maka dapat ditarik beberapa simpulan dalam penelitian ini diantaranya sebagai berikut.

1. Sanksi pidana bagi perusahoun jika terjadi kecelakaan dalam belajar mengemudi di jalan raya secara hukum sanksi pidananya tidak diatur bagi perusahaan, namun apabila terjadi kecelakaan di jalan raya saat belajar pertanggungjawaban pidananya semua ditanggung oleh instruktur atau pendamping pengguna jasa (peserta didik). Sebagaimana yang diatur di dalam Pasal 79 ayat (1) dan (2), Undang- Undang Lalu Lintas dan Angkutan Jalan yang menegaskan bahwa setiap cal on pengemudi pada saat belajar mengemudi atau mengikuti ujian praktek mengemudi wajib didampingi instru ktur atau penguji dan lnstru kiur atau penguji sebagai mana dimaksud ayat (1) bertanggungjawab atas pelanggaran dan kecelakaan lalu lintas yang terjadi saat calon pengemudi belajar atau menjalani ujian.

2. Pertanggungjawaban perdata pihak perusahaan dalam hal terjadin ya kecelakaan di jalan raya adalah perusahaan berkewajiban untuk memberikan bantuan kepada ahli waris atas biaya pengobatan dan pemakaman korban kalau kecelakaan mengakibatkan meninggal dunia.

\section{Saran}

Dari pembahasan tersebut adapun beberapa saran yang disampaikan peneliti dalam penelitian ini kepada masyarakat, agar memilih tempat pelatihan yang memiliki izin dari pemerintah terkait dan terakreditasi sehingga lebih aman dalam belajar mengemudi. Kepada pengusaha, dalam melaksanakan kegiatan pendidikan mengemudi agar selalu beroperasi sesuai dengan ketentuan peraturan perundangundangan. Kepada pemerintah, agar selalu melakukan pengawasan terhadap perusahaan yang bergerak dalam bidang pendidikan mengemudi sehingga dapat memberikan rasa a man kepada pengguna jasa.

\section{DAFTAR PUSTAKA}

Azizah, P. N. (2019). Analisis Tanggung Jawab Penyedia Layanan Jasa Kursus Mengemudi Mobil (Studi Pada Yayasan Pendidikan Dan Keterampilan. Aliah. Makassar.

Bambang, S. (2002). Metodologi Penelitian Hukum (Cet. 4). PT Raja Grafindo Persada. Jakarta.

Hartono, S. (1994). Penelitian Hukum Di Indonesia Pada Akhir Abad Ke 20 (Ed.1). Penerbit Alumni. Bandung.

Jauhari, L., Erdianto, \& Edorita, W. (2015). Pertanggungjawaban Pidana Terhadap Calon Pengemudi Saat Belajar Mengemudi Atas Pelanggaran Kecelakaan Lalu Lintas Menurut Undang Undang Nomor 22 Tahun 2009 Tentang Lalu Lintas Dan Angkutan Jalan. Jumal Online Mahasiswa, Vol.2 (2).

Prodjodikoro, W. (1991). Hukum Perdata Tentang Persetujuan-Persetujuan Tertentu.Sumur. Bandung 
Raenaldi, A., PJ, N. S., \& Purwoto. (2016). Pertanggungjawaban Pidana Mengenai Lembaga Pelatihan Mengemudi Mobil Yang Membahayakan Pengguna Jalan Umum. Fakultas Hukum, Universitas Diponegoro, Indonesia.

R.Subekti, \& Tijitrosudibio. (2002). Kitab Undang-Undang Hukum Perdata. Jakarta.

Soekanto, S. (1990). Polisi dan lalu lintas (analisis menurut sosiolog hukum). Mandar Maju. Bandung.

Tjakranegara, S. (1995). Hukum pengangkutan barang dan penumpang. Rineke Cipta. Jakarta.

Waluyo, B. (2016). Penegakan Hukum Indonesia. Sinar Grafika, Jakarta. 